\title{
Development and Testing of a Portable Sisal Fibre Extractor for Small Scale Growers
}

\author{
R. K. Naik* and G. Kar \\ ICAR-Central Research Institute for Jute and Allied Fibres, Barrackpore, \\ Kolkata, West Bengal, India \\ *Corresponding author
}

\section{A B S T R A C T}

\begin{tabular}{|l|}
\hline Key w or d s \\
$\begin{array}{l}\text { Extractor, Natural } \\
\text { fibre, Sisal, } \\
\text { Marginal soil, } \\
\text { Plastic }\end{array}$ \\
\hline Article Info \\
\hline $\begin{array}{l}\text { Accepted: } \\
\text { 17 September 2020 } \\
\text { Available Online: } \\
10 \text { October } 2020\end{array}$ \\
\hline \hline
\end{tabular}

Sisal is one of the natural fibre crops grown in poor and marginal soil. Fibre products obtained from sisal has huge potential to replace plastics. But extraction of fibre from sisal leaves is the most critical operation. For small-scale sisal fibre extraction, a portable fibre extractor was designed, developed and its performance was evaluated. The fibre extractor provides improved sisal leaf processing with less energy input and reduced cost. It was observed that the throughput capacity and material capacity of the fibre extractor was found to be 330-380 kg leaves/hour and $12-14 \mathrm{~kg}$ dry fibre /hour, respectively with a design efficiency of 50 per cent and average fibre yield of 4 percent per leaf. It was also found that maximum fibre extraction efficiency of $96.66 \%$ can be achieved by processing the freshly harvested sisal leaves (80-85 \% moisture content) at a beater cylinder peripheral speed of $10.69 \mathrm{~m} / \mathrm{s}(510.6 \mathrm{rpm})$ and beater blade clearance of $0.80 \mathrm{~mm}$ with fixed knife unit. It was calculated that unit fibre extraction cost per quintal of dry sisal fibre by using developed sisal fibre extractor is Rs. 445/-.

\section{Introduction}

Sisal is known for its leaf fibre (hard fibre), belongs to the genus Agave of the family Agavaceae (Fig. 1). The sisal plant produces about 200-250 leaves during its life cycle of 11-12 years (Wilson, 1971). The fibre is obtained from the mature leaves by beating and scraping operation either by hand or machine or retting process for removal of inner pulpy material. The fibre quantity accounts about $4-5 \%$ of the green leaf biomass by weight (Bachthaler, 2006; Moore, 2008). Sisal occupies the $6^{\text {th }}$ place among fiber producing plants and representing $2 \%$ of the world's production of plant fibers (Rhem and Espig, 1991; Hodgkiss, 2008).

Among the many sisal species Agave sisalana contributes $85 \%$ of the total sisal fibre production in the world (Sarkar et al., 2017). In India sisal is mainly found in the semi-arid regions of Odisha, Andhra Pradesh, Bihar, Karnatak, Maharasthra and West Bengal (Biswas, 2007). At present Brazil is the largest producer of sisal fibre in the world, followed by China, Kenya and Tanzania (FAO, 2003). 
The fibre obtained from sisal leaf is thicker than many other natural plant fibres and itis valued for its outstanding strength and durability. Due to some special qualities i.e. good dying ability, less moisture absorbing ability and low maintenance etc. of fibre, it is utilized in the cordage industries for manufacture of general and marine ropes, twines and carpets. The fibre is also utilized for making of coarse textile materials like nets, mats, wall coverings and making of handicrafts (Lock, 1969).

\section{Existing sisal fibre extraction process}

Retting or hand processing method of sisal fibre extraction is a tedious exercise and unhygienic. The introduction of 'raspador' decorticator machine has made beginning in mechanical fibre extraction in India during early part of $20^{\text {th }}$ century. Later, automatic decorticators were installed in some sisal plantations like Nildungri, Sitlenpali (Odisha) but, these machines were proved unsuccessful because of higher cost of fibre extraction. Hence, under existing conditions, it was recommended to extract sisal fibre with 'raspador' decorticator machine only (Borkar and Pandey, 1997). The 'raspador' decorticator works on the principle of rapid beating and scrapping of leaves progressively down its length through a rotating beater revolves at about $900 \mathrm{rpm}$ having blades on its periphery. The machine involves twodirectional leaf feeding for complete fibre extraction. Fibre extraction capacity of the machine is about $9-10 \mathrm{~kg}$ dry sisal fibre per machine-hour depending on the frequency of leaf feeding. The machine is operated by a 5hp 3-phase electric motor or $7.5 \mathrm{hp}$ Diesel engine (Naik et al., 2011). Operational cost of 'raspador' type decorticator is more due to high cost of electricity or diesel fuel energy and for this, utilization of these decorticators are confined to farms having large plantations.
Sisal cultivation in India, although began at the same time as in East Africa, its area of cultivation and fibre production is very low. Every year appreciable quantities of sisal fibre are being imported to meet the local demand. Sisal plants are found throughout the country on hedges, bunds, waste lands etc. but; these are not utilized commercially for fibre extraction. The high cost involvement in fibre extraction and non-availability of suitable fibre extraction machines have been reported as major limitation in sisal fibre production in India (Borkar and Pandey, 1997). Therefore, it was felt to develop a simple and low-cost portable sisal fibre extractor to cater the need of small scale sisal growers in remote rural area.

\section{Development of machine}

The prime-mover for the machine was selected as electric motor of single-phase $3 \mathrm{hp}$ capacity. The units in the conceptual design of the sisal fibre extractor were: beating and scraping unit and conveying unit. The scraping unit consists of a rotating beater to which a set of blades (MS Angle) were fixed with nut and bolt on the peripheral surface at equidistant points and rests on a shaft which turn on a pair of self-aligning bearings fixed on a frame. The fixed knife unit consists of a metal sheet with concave breast-plate having same width as the beater. The beater is of 250 $\mathrm{mm}$ length and $400 \mathrm{~mm}$ diameter having 12 numbers of blades on its periphery. The fixed knife unit placed rigidly beside the beater by maintaining desired clearance of about 0.5 $1.0 \mathrm{~mm}$ in between them at the top and $40-$ $60 \mathrm{~mm}$ at the lowest part to allow the leaf pulp to get away easily. This clearance allows sisal leaf to enter in between fixed knife unit and beater for the rasping action.

The conveying unit consists of feeding chute placed on a feeding platform, which covers the entire knife unit. It consists of air vents for 
discharge of back air near the beater cylinder and fabricated in such a way that, at the opening of feeding chute, one leaf can be feed at a time safely. Feeding chute permits the sisal leaf to enter its maximum length into the machine by hand. Metal sheet covering the motor serves as a extraction waste collector.

The operational parts of the machine like beater and fixed knife unit are mounted on a machine stand of desired height, which facilitates operation of the machine comfortably in standing posture. The machine stand facilitates mounting of motor, power transmission unit, operational parts, feeding chute, machine waste collector and ground wheels. The power transmission from motor to the beater cylinder is obtained through $\mathrm{V}$ belt and pulleys. The four ground wheels allow movement of the machine, only in length-wise direction and helps in obtaining better stability during its operation. The developed portable sisal fibre extractor machine is given in (Fig. 2).

\section{Materials and Methods}

The machine works on the principle of rapid beating and scrapping of leaves progressively down its length. The beater revolves towards the operator at a speed of about $600 \mathrm{rpm}$. Sisal leaf is fed manually by the tip end first into the machine up to $3 / 4^{\text {th }}$ of length. The beater which rotates clockwise at high speed pulls the leaf downwards and is beaten by the blades and chip off the leaf tissues at closely spaced intervals against the fixed knife unit. When the operator pulls out the leaf, the beater scrap out all the non-fibrous tissue and then un-decorticated butt end is fed into the machine for complete extraction process. The machine needs two workers for its operation; one for leaf feeding and manipulation into the machine and the other for supply of sisal leaves to the operator, collection and disposal of machine waste and extracted fibre etc. The fibre extraction capacity of the machine varies with the operator's efficiency of leaf feeding and manipulation into the machine.

For testing the fibre extraction efficiency of the developed portable fibre extractor, sisal leaves of the species Agave sisalana were taken. Three ranges of beater peripheral speed at load condition were used such as $9.05 \mathrm{~m} / \mathrm{s}$ (432.3 rpm), $10.69 \mathrm{~m} / \mathrm{s}$ (510.6 rpm) and 12.50 $\mathrm{m} / \mathrm{s}(597.3 \mathrm{rpm})$ during the test. The speeds were obtained by changing the beater v-pulley and belt. Three levels of beater clearance i.e. $0.60 \mathrm{~mm}, 0.80 \mathrm{~mm}$ and $1.00 \mathrm{~mm}$ were taken. Three levels of leaf moisture content i.e. 80$85 \%$ (on the day of harvest), 60-65\% ( $2^{\text {nd }}$ day after harvest) and 50-55 \% ( $3^{\text {rd }}$ day after harvest) were taken. The total treatment combinations were 27 for the experiment. For each observation the mean of the three replications were taken.

For each test run a known weight of sisal leaf were processed. The fibre extraction time for each test run was recorded by a stop watch. The fibres were collected, washed and sun dried. To study the economic use of the fibre extractor the annual use of machine was assumed to be 1000 hour.

\section{Results and Discussion}

During the test it was observed that the fibre extraction efficiency varied from 76.47 to $96.66 \%$. The maximum fibre extraction efficiency of $96.66 \%$ was obtained at beater peripheral speed of $10.69 \mathrm{~m} / \mathrm{s}(510.6 \mathrm{rpm})$ on freshly harvested leaves (leaf mc 80-85\%) at beater blade clearance of $0.80 \mathrm{~mm}$. The minimum fibre extraction efficiency of 76.47 $\%$ was observed at beater peripheral speed of $12.50 \mathrm{~m} / \mathrm{s}(597.3 \mathrm{rpm})$ on three days stored leaves (leaf mc 50-55\%) at beater blade clearance of $1.00 \mathrm{~mm}$. It was observed that in most of the machine conditions the extraction efficiency increased with increase in speed 
from $9.05 \mathrm{~m} / \mathrm{s}$ to $10.69 \mathrm{~m} / \mathrm{s}$ but decreases as the speed increased to $12.50 \mathrm{~m} / \mathrm{s}$. This shows that the speed $10.69 \mathrm{~m} / \mathrm{s}$ is optimum as shown in Fig. 3.

Table.1 Testing of sisal fibre extractor (Peripheral speed $=10.69 \mathrm{~m} / \mathrm{s}$,

Clearance $=0.8 \mathrm{~mm}$, leaf $\mathrm{mc} 80-85 \%$ )

\begin{tabular}{|c|c|c|c|c|}
\hline Test No. & $\begin{array}{c}\text { Weight of leaves, } \\
\mathbf{~ k g}\end{array}$ & $\begin{array}{c}\text { Total time, } \\
\text { minute }\end{array}$ & $\begin{array}{c}\text { Dry fibre } \\
\text { obtained, g }\end{array}$ & $\begin{array}{c}\text { Dry fibre as \% of } \\
\text { leaf weight, \% }\end{array}$ \\
\hline $\mathbf{1}$ & 9.45 & 1.62 & 395 & 4.17 \\
\hline $\mathbf{2}$ & 9.45 & 1.60 & 370 & 3.91 \\
\hline $\mathbf{3}$ & 9.45 & 1.66 & 385 & 4.07 \\
\hline $\mathbf{4}$ & 9.45 & 1.65 & 369 & 3.90 \\
\hline $\mathbf{5}$ & 9.45 & 1.64 & 375 & 3.96 \\
\hline Average & 9.45 & 1.63 & 378.8 & 4.00 \\
\hline
\end{tabular}

Fig.1 Sisal plant

Fig.2 Portable sisal fibre extractor
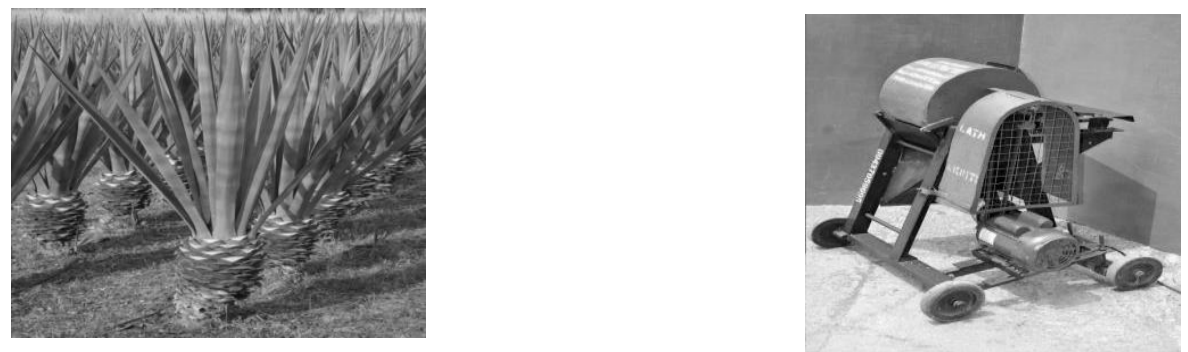

Fig.3 Effect of beater clearance, leaf moisture content and beater cylinder speed on extraction efficiency
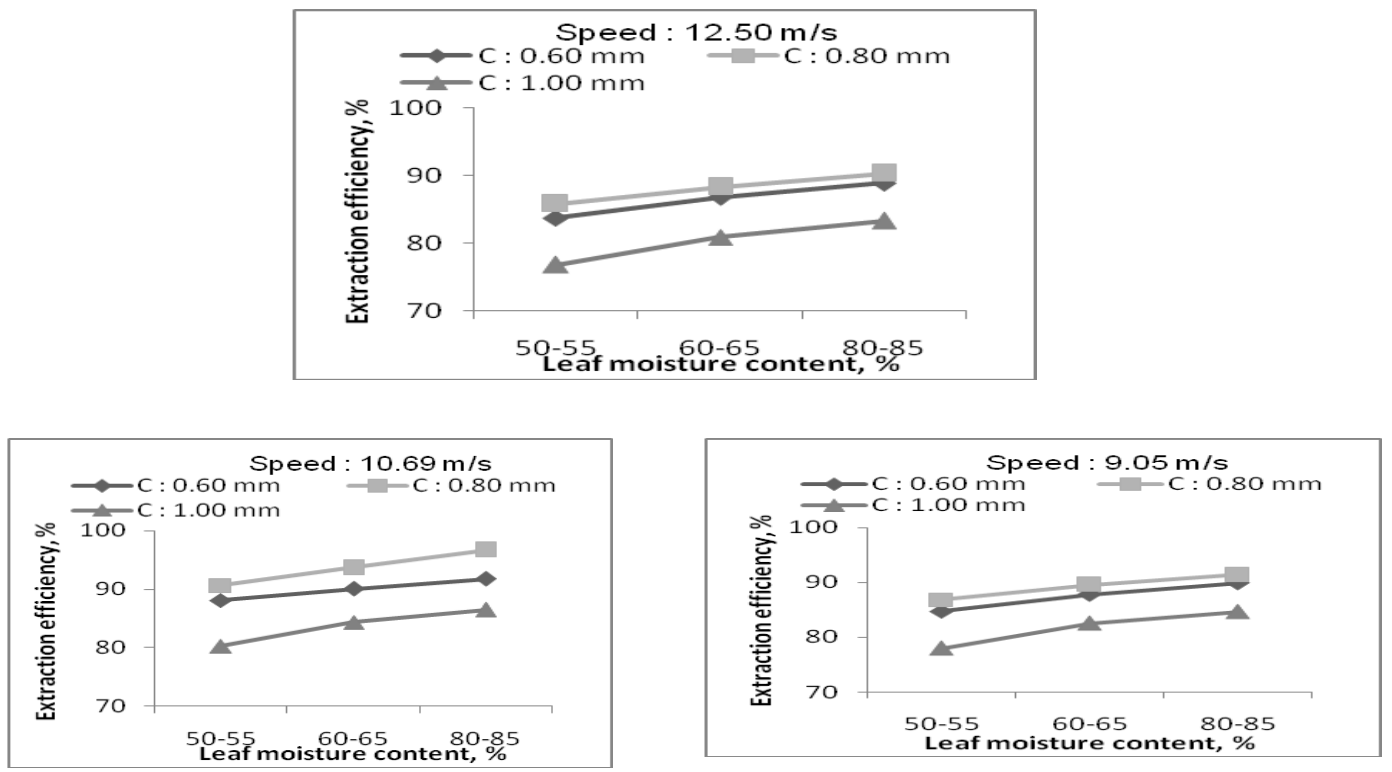
The fibre extraction efficiency was observed to decrease with increase in clearance between beater blades and fixed knife unit. The $0.80 \mathrm{~mm}$ clearance caused maximum extraction efficiency with minimum loss of fibre during operation.

The fibre extraction efficiency decreases from maximum of 98.01 per cent to 76.47 per cent as the moisture content was decreased from $80-85$ per cent to 50 - 55 per cent i.e. from freshly harvested leaves to two days stored leaves.

The rate of decrease in extraction efficiency was higher as the decrease in moisture content from 60 - 65 per cent to 50 - 55 per cent. This indicates that the fibre extraction must be carried out immediately after the harvest of sisal leaves to achieve maximum extraction efficiency in mechanical fibre extraction process.

The average time taken to process 15 leaves was 1.63 minutes and details are presented in Table 1 . The machine capacity based upon the average leaf weight of $0.63 \mathrm{~kg}$ was calculated to be $350 \mathrm{~kg}$ of fresh sisal leaves per hour. The actual capacity of the developed portable sisal fibre extractor with the optimum specifications was found out to be $14 \mathrm{~kg}$ of dry sisal fibre per hour. The design efficiency, $\mathrm{DE} \%$ of the prototype fibre extractor with respect to design capacity of $28 \mathrm{~kg}$ of dry sisal fibre per hour (Kawongolo, 2002) for small sisal farmer was calculated as

$$
\text { DE } \%=\frac{14}{28} \times 100=50 \%
$$

The per cent yield (PY \%) is the amount of dry fibre expressed as percentage of fresh weight of sisal leaves. For the portable fibre extractor, the per cent yield of fibre was found out to be $4 \%$, which is within the recommended range of 3 to $5 \%$ of fresh green weight of sisal leaf (Weindling, 1947).
The economic analysis of the portable sisal fibre extractor reveals that the cost of extraction of sisal fibre is Rs. 445.00 per quintal of dry fibre using single-phase $3 \mathrm{hp}$ electric motor, which is a suitable power source available in village areas, whereas for existing 'raspador' decorticator it isRs. 665.00 using three-phase $5 \mathrm{hp}$ electric motor.

In conclusion the maximum fibre extraction efficiency and minimum fibre loss was obtained with freshly harvested sisal leaves at optimum beater peripheral speed of $10.69 \mathrm{~m} / \mathrm{s}$ and $0.80 \mathrm{~mm}$ clearance. The dry fibre content was $4 \%$ of fresh green weight of leaf biomass. The portable sisal fibre extractor not only using less energy for its operation but also extracting $55 \%$ more fibre than existing 'raspador' decorticator. The fibre extraction can be feasible in the sisal plantation area using a small diesel engine in the absence of electric power source. The low powered machine / technology for sisal fibre extraction will be feasible and economical for small scale sisal growers in the remote and tribal areas.

\section{References}

Bachthaler, G. 2006. http://www. nnfcc.co.uk/Crops/info/Sisal.html.

Biswas, D. K. 2007. Sisal: a multi-purpose plant for low rainfall areas. Bulletin No. 8/2007, ICAR-CRIJAF, Barrackpore. pp-11.

Borkar, U. N. and Pandey, S. N. 1997. Fibre extraction with 'Raspador' decorticator. J. Sci. Ind. Res. (56): 353-356.

FAO 2003. Food and Agriculture Organization of the United Nations: Statistics Division. http://faostat.fao.org.

Hodgkiss, R. J. 2008. The succulent plant page. Families of succulent plants. The Agave Page. Agavaceae = Agave 
Family, Century Plants D. and Pradhan, S.C. 2011b. Studies www.succulent-plant.com.

Kawongolo, J.B., Kibalama, J.S. and Brown, L. 2002. Design of a decorticator for small scale sisal processing in Uganda. Paper presented in ASAE annual international meeting. Chicago, USA.

Lock, G. W. 1969. Sisal: thirty years sisal research in Tanzania. $2^{\text {nd }}$ Edition. Logmans, London. pp- 365.

Moore, H. 2008. http://www.coopext. colostate.edu /TRA /PLANTS / chinlecactus.html.

Naik, R.K., Dash, R.C., Pradhan, S.C. and Goel, A.K. 2010a. Energy requirement for production and extraction of fibre from sisal (Agave sisalana). J. Res. Orissa Univ. Agric. Tech. 28 (1 \& 2):131-136.

Naik, R.K., Dash, R.C., Goel, A.K., Behera, on leaf manipulation in mechanical extraction of fibre from sisal (Agave sisalana). J. Res. Orissa Univ. Agric. Tech. 29 (1\& 2):50-52.

Rehm, S. and Espig, G. 1991. The cultivated plants of the tropics and sub-tropics. http://www.nnfc.co.uk/crop/info/sisal. html.

Sarkar, S. and Jha, A.K. 2017. Research for sisal (Agave spp.) production in India. International Journal of Current Research. 9(11):61136-61146.

Weindling L. 1947. Long vegetable fibres. Columbia University Press, New York. Pp. 72-104.

Wilson P. 1971. Sisal. Hard Fibres Research Series No. 8, FAO, Rome: 1-236.

\section{How to cite this article:}

Naik, R. K. and Kar, G. 2020. Development and Testing of a Portable Sisal Fibre Extractor for Small Scale Growers. Int.J.Curr.Microbiol.App.Sci. 9(10): 2467-2472. doi: https://doi.org/10.20546/ijcmas.2020.910.295 